\title{
RIPARIAN-ZONE AMPHIBIANS AND REPTILES WITHIN THE BROAD RIVER BASIN OF SOUTH CAROLINA
}

\author{
MADELEINE M. KERN, JACQUELYN C. GUZY, STEVEN J. PRICE ${ }^{1}$, STEPHANIE D. HUNT, \\ EVAN A. ESKEW ${ }^{2}$, and MICHAEL E. DORCAS \\ ${ }^{1}$ Present address: Department of Forestry, University of Kentucky, Lexington, KY 40546, USA \\ Email: steven.price@ky.edu \\ ${ }^{2}$ Present address: Department of Wildlife, Fish, and Conservation Biology, University of California, Davis, \\ Davis, CA 95616, USA; Email: eaeskew@ucdavis.edu \\ Corresponding author email: jaguzy@davidson.edu/Phone: 7048942768 \\ Department of Biology, Davidson College, Davidson, NC 28035
}

\begin{abstract}
An inventory of the Broad River Basin in South Carolina documented distribution and species richness of amphibians and reptiles of the area, focusing primarily on riparian zones. A list of 92 potentially occurring species was assembled for the area. Multiple survey methods were used including active searches, manual anuran calling surveys, and turtle trapping to document the herpetofauna. Using these techniques, 14 anuran, 9 salamander, 7 lizard, 16 snake, and 8 turtle species were documented. Seven of these species were of conservation concern in South Carolina. The Broad River Basin supports a diverse array of amphibian and reptile species associated with both wetland and riverine habitats. As water resources, energy demand, and urbanization continue to increase in the Piedmont region, these baseline data have important implications for conservation and future land management.
\end{abstract}

Key Words: Herpetofauna; Herpetological Inventory; Pacolet River; Piedmont, Southeast; Wetlands.

\section{INTRODUCTION}

Amphibians and reptiles are currently experiencing rapid population declines and are generally considered among the most threatened animal groups in North America (Gibbons et al. 2000; Semlitsch 2003; Wake and Vredenburg 2008). Of the 450 species that occur in the United States, half are found in the Southeast (Gibbons 1993; Palmer and Braswell 1995; Conant and Collins 1998; Tuberville et al. 2005), where they play critical roles in ecosystems. Amphibians and reptiles are ectotherms with higher energy conversion efficiencies than other vertebrates, which allow them to devote high proportions of assimilated energy to growth and reproduction (Pough 1980). Thus, in some ecosystems they can exceed the biomass of all other vertebrate species combined (Godley 1980; Congdon and Gibbons 1989; Petranka and Murray 2001). Amphibians and reptiles play important roles as both predators and prey because of their high abundances, serving as crucial trophic links within ecosystems (Taylor et al. 1988; Gibbons and Dorcas 2004). Consequently, the status of herpetofaunal populations is often suggested as an indicator of environmental integrity (Gibbons 1988; Vitt et al. 1990; Knutson et al. 1999; Gibbons et al. 2000).

\section{Study Area}

The Broad River Basin in the Western Piedmont of South Carolina covers over 600,000 ha and more than 4 million stream miles. Approximately $60 \%$ of the basin is forested upland, with relatively small areas of agriculture $(23.8 \%)$ and urban land (9.8\%; SCDHEC 2011) compared to other areas in the Piedmont of the Southeastern U.S. (Griffith et al. 2003; Price et al. 2006). The South Carolina State Assembly recognized the Broad River as a State Scenic River in 1991 (SCDNR 2009) because of the high percentage of relatively undisturbed riverine and riparian habitats. Such habitats provide critical environments for many amphibian and reptile species (Burbrink et al. 1998; Eskew et al. 2012). Riparian habitats within the Broad River Basin likely contain a high diversity of amphibians and reptiles; however, like most of South Carolina (Dorcas et al. 2006), little is known about the distribution of herpetofauna in these areas. This study documented distribution, species richness, and abundances of amphibians and reptiles in riparian zones within the Broad River Basin in South Carolina. Data resulting from this investigation can provide a useful baseline for future studies of herpetofauna in the area and can help with land management decisions within this region.

\section{METHODS}

\section{Study Sites}

The Broad River Basin is situated in western North Carolina and northern and central South Carolina; however, we restricted our study sites to eight counties 


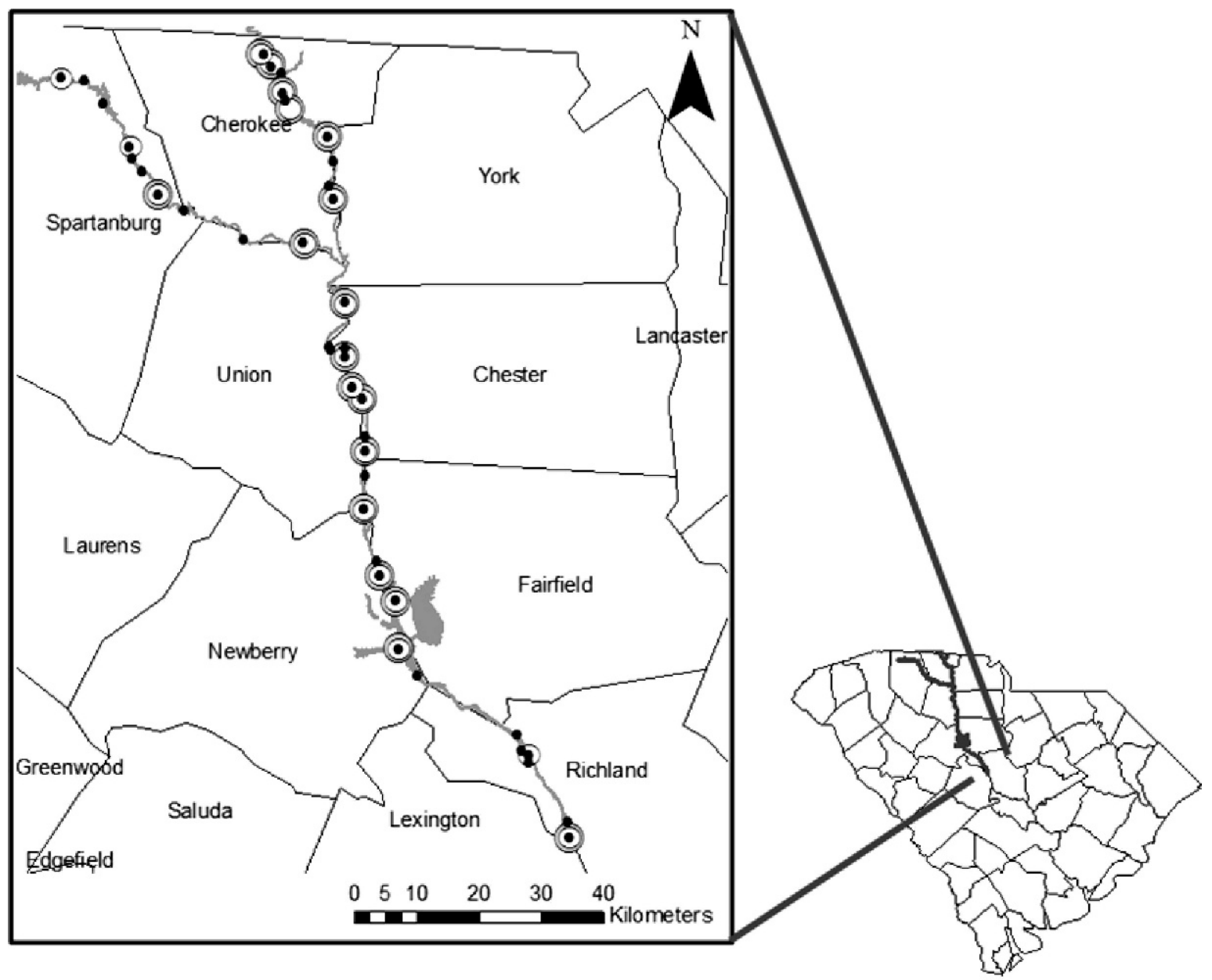

Fig. 1. Map of the Broad River Basin in South Carolina showing the location of each study site. The black circles represent anuran calling survey sites, the white represent active search sites, and the grey represent sites where turtle trapping was conducted.

in the Piedmont of South Carolina (Fig. 1). During 2010 and 2011 we sampled 42 riparian sites along both the Broad and Pacolet rivers (Fig. 1); these sites represented several habitat types including riverbanks, forested riparian zones, reservoirs, emergent wetlands, and ephemeral wetlands. A geographic information system (ArcGIS 9.1; ESRI 2009) was used with layers from the National Wetland Inventory (NWI 2011) and the National Land Cover Database (NLCD 2011) to identify approximately 200 riparian wetlands within the basin. After groundtruthing each of the sites to determine accessibility, we used a stratified random design to select 42 study sites at which to conduct surveys (see Eskew et al. 2012 for more information on study site selection). Survey sites were an average of $125.12 \mathrm{~m}$ (SE 26.49) from the river channel.

\section{Sampling Methods}

Unfortunately, there were no publications or documents that provided detailed distribution records for amphibians and reptiles in South Carolina. Thus, to create an accurate potential species list prior to surveys,
1) all amphibian and reptile records were requested for 8 counties (Cherokee, Chester, Fairfield, Newberry, Richland, Spartanburg, Union, York) in South Carolina from 64 museums, universities, and other appropriate organizations (i.e., participants in Herpnet), 2) the Carolina Herp Atlas (www.carolinaherpatlas.org; Price and Dorcas 2011) was searched for the same areas, and $3)$ the range maps from Conant and Collins were examined (1998). Federally- and state-listed Threatened or Endangered species and South Carolina Species of Special Concern were of particular interest.

We used time-constrained active searches, anuran calling surveys, and turtle trapping to document reptiles and amphibians at each study site. Three anuran calling surveys were conducted per season (winter, spring, and summer) at all 42 sites between 1845 and 0130 hrs. Simultaneous calling surveys were conducted by two persons listening for five min and recording all species heard. Surveys of this duration are sufficient to detect most anuran species found in the North Carolina Piedmont (Gooch et al. 2006). In totally, 15 anuran surveys were conducted at each study site. 


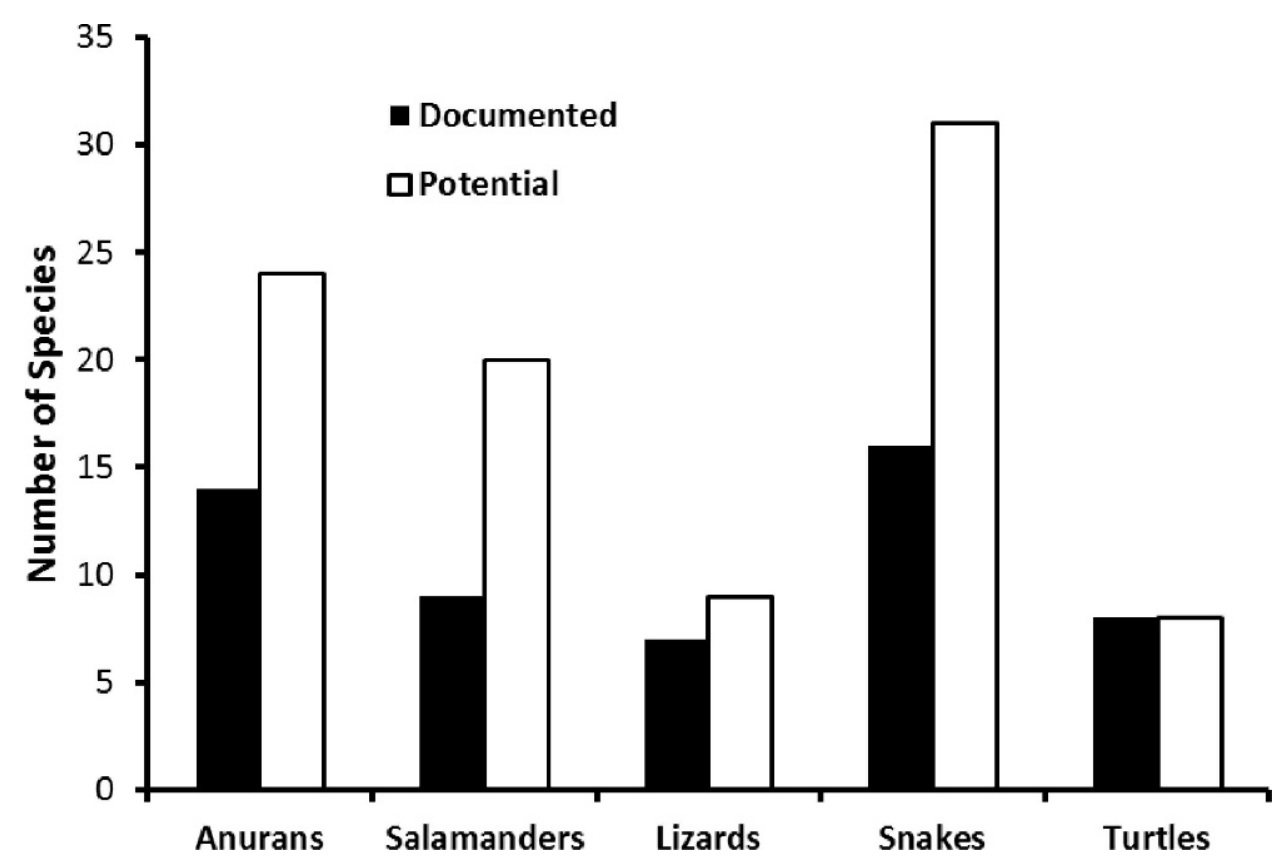

FIG. 2. Number of potentially occurring and documented species for herpetofaunal groups in the Broad River Basin in South Carolina.

Active searches were conducted at 21 sites over the course of two years. Two searches were conducted at each site in the fall and three in the summer of 2010 . Additionally, three searches of each site were made during the spring of 2011, resulting in a total of 13 searches per site. Each survey consisted of two persons independently searching the site for $30 \mathrm{~min}$ to identify reptile and amphibian species (Crump and Scott 1994). A few searches were made by one person, and these lasted one hour. Each active search was conducted during daylight. All individuals captured during this study were released at the site of capture after identification. Additionally, semi-aquatic turtles were trapped at 18 sites. Three hoop net traps baited with sardines were placed in shallow water for $24 \mathrm{hrs}$ at each site. All turtles captured were identified to species and released (Failey et al. 2007). All species detected outside of any survey were recorded as incidental findings.

Species observed during active searches and turtle trapping were ranked according to their abundances, which were determined based on the total number of individuals detected. Anuran presence during surveys was used rather than abundance rankings because counts of individuals were not possible. Those species with 1-5 observations were considered "rare," 6-20 "somewhat rare," 21-100 "common," and species with more than 100 observations were "abundant."

Of particular interest were Species of Special Concern and those federally- and state-listed. In South Carolina, Acris crepitans (Northern Cricket Frog) is listed as a species of Special Concern and was difficult to distinguish in vocalization and appearance from Acris gryllus (Southern
Cricket Frog), a species not currently of conservation concern. Because of the difficulty identifying these two species, recorded vocalizations and specimens were sent to J. Micancin who specializes in Acris identification.

\section{RESULTS AND DISCUSSION}

We determined that 92 reptile and amphibian species (24 anuran, 20 salamander, 9 lizard, 31 snake, and 8 turtle species) potentially occurred in the Broad River Basin in South Carolina. Our surveys recorded 54 species, specifically 14 anuran, 9 salamander, 7 lizard, 16 snake, and 8 turtle species (Fig. 2, Tables 1 and 2). Eleven potentially occurring species were either of Special Concern or were priority species for South Carolina (SCDNR 2005), and seven of these 12 species were documented during surveys (Table 3 ).

Our sampling methods were designed to detect as many species of amphibians and reptiles as possible and not to estimate relative or absolute abundances. However, based on extensive surveying, qualitative comments can be made on their abundances within the Broad River Basin (Fig. 2). Of the 54 total species documented, 17 are considered to be rare, 15 somewhat rare, 13 common, and 9 abundant (Tables 1 and 2). Species requiring wetlands or temporary ponds (which are numerous within the Broad River Basin) for breeding and foraging, such as Anaxyrus fowleri, Ambystoma opacum, and Acris crepitans (Martof et al. 1980), were abundant. Other species which do not necessarily require wetland habitat, such as Anolis carolinensis, Sceloporus undulatus and Terrapene carolina (Martof et al. 1980; Conant and Collins 1998), 
Table 1. Documented amphibians of the Broad River Basin in South Carolina and the counties in which each was found. Species are classified as rare (1-5 observations), somewhat rare (6-20 observations), common (21-100 observations), or abundant (101 or more observations). Active searches (AS), anuran calling surveys (CS) and turtle trapping (TT) were conducted in Cherokee (Ck), Chester (Cs), Fairfield (F), Newberry (N), Richland (R), Spartanburg (S), Union (U), and York (Y) counties (In-incidental findings, Rk—roadkill).

\begin{tabular}{|c|c|c|c|c|}
\hline Scientific Name & Common Name & Abundance & Counties & Method of Detection \\
\hline Acris crepitans & Northern Cricket Frog & Abundant & $\mathrm{Ck}, \mathrm{Cs}, \mathrm{F}, \mathrm{N}, \mathrm{R}, \mathrm{S}, \mathrm{U}, \mathrm{Y}$ & $\mathrm{AS}, \mathrm{CS}$ \\
\hline Anaxyrus americanus & American Toad & Common & $\mathrm{Ck}, \mathrm{Cs}, \mathrm{F}, \mathrm{N}, \mathrm{R}, \mathrm{S}, \mathrm{U}, \mathrm{Y}$ & $\mathrm{AS}, \mathrm{CS}$ \\
\hline Anaxyrus fowleri & Fowler's Toad & Abundant & $\mathrm{Ck}, \mathrm{Cs}, \mathrm{F}, \mathrm{N}, \mathrm{R}, \mathrm{S}, \mathrm{U}, \mathrm{Y}$ & $\mathrm{AS}, \mathrm{CS}, \mathrm{In}$ \\
\hline Anaxyrus terrestris & Southern Toad & Rare & $\mathrm{R}$ & $\mathrm{AS}, \mathrm{CS}$ \\
\hline Gastrophryne carolinensis & Eastern Narrowmouth Toad & Common & $\mathrm{Ck}, \mathrm{F}, \mathrm{N}, \mathrm{R}, \mathrm{U}$ & AS \\
\hline Hyla chrysoscelis & Cope's Gray Treefrog & Abundant & $\mathrm{Ck}, \mathrm{Cs}, \mathrm{F}, \mathrm{N}, \mathrm{R}, \mathrm{S}, \mathrm{U}, \mathrm{Y}$ & $\mathrm{AS}, \mathrm{CS}$ \\
\hline Hyla cinerea & Green Treefrog & Common & $\mathrm{Ck}, \mathrm{Cs}, \mathrm{F}, \mathrm{N}, \mathrm{R}, \mathrm{S}, \mathrm{U}, \mathrm{Y}$ & $\mathrm{AS}, \mathrm{CS}$ \\
\hline Lithobates catesbeianus & Bullfrog & Abundant & $\mathrm{Ck}, \mathrm{F}, \mathrm{N}, \mathrm{R}, \mathrm{S}, \mathrm{U}, \mathrm{Y}$ & AS, CS,In \\
\hline Lithobates clamitans & Green Frog & Abundant & $\mathrm{Ck}, \mathrm{Cs}, \mathrm{F}, \mathrm{N}, \mathrm{R}, \mathrm{S}, \mathrm{U}, \mathrm{Y}$ & AS,CS,In \\
\hline Lithobates palustris & Pickerel Frog & Somewhat Rare & $\mathrm{Ck}, \mathrm{Cs}, \mathrm{N}, \mathrm{S}, \mathrm{U}, \mathrm{Y}$ & $\mathrm{AS}, \mathrm{CS}$ \\
\hline Lithobates sphenocephalus & Southern Leopard Frog & Abundant & $\mathrm{Ck}, \mathrm{Cs}, \mathrm{F}, \mathrm{N}, \mathrm{R}, \mathrm{S}, \mathrm{U}, \mathrm{Y}$ & $\mathrm{AS}, \mathrm{CS}, \mathrm{Rk}$ \\
\hline Pseudacris crucifer & Spring Peeper & Common & $\mathrm{Ck}, \mathrm{Cs}, \mathrm{F}, \mathrm{N}, \mathrm{R}, \mathrm{S}, \mathrm{U}, \mathrm{Y}$ & $\mathrm{AS}, \mathrm{CS}$ \\
\hline Pseudacris feriarum & Upland Chorus Frog & Common & $\mathrm{Ck}, \mathrm{Cs}, \mathrm{F}, \mathrm{N}, \mathrm{R}, \mathrm{S}, \mathrm{U}, \mathrm{Y}$ & AS,CS \\
\hline Scaphiopus holbrookii & Eastern Spadefoot Toad & Somewhat Rare & $\mathrm{N}, \mathrm{R}$ & AS,In \\
\hline Ambystoma maculatum & Spotted Salamander & Common & $\mathrm{S}$ & AS \\
\hline Ambystoma opacum & Marbled Salamander & Abundant & $\mathrm{Ck}, \mathrm{Cs}, \mathrm{N}, \mathrm{R}, \mathrm{U}, \mathrm{Y}$ & AS \\
\hline Desmognathus fuscus & Northern Dusky Salamander & Common & $\mathrm{Ck}, \mathrm{R}, \mathrm{S}$ & AS \\
\hline Eurycea chamberlaini & Chamberlain's Dwarf Salamander & Rare & $\mathrm{R}$ & AS \\
\hline Eurycea cirrigera & Southern Two-lined Salamander & Common & $\mathrm{Ck}, \mathrm{Cs}, \mathrm{S}$ & AS \\
\hline Eurycea guttolineata & Three-lined Salamander & Somewhat Rare & $\mathrm{Ck}, \mathrm{N}, \mathrm{S}$ & AS \\
\hline Gyrinophilus porphyriticus & Spring Salamander & Rare & $\mathrm{S}$ & AS \\
\hline Notophthalmus viridescens & Eastern Newt & Common & $\mathrm{Ck}, \mathrm{S}, \mathrm{U}$ & AS \\
\hline Plethodon cylindraceus & White-spotted Slimy Salamander & Somewhat Rare & $\mathrm{Ck}, \mathrm{S}$ & AS \\
\hline
\end{tabular}

were also relatively common in the riparian zones surveyed.

Thirty-eight of the 92 potential species were not observed (Appendix 1). The lack of observations of many salamanders and snakes is likely because of low detection probability. Many salamanders are fossorial and difficult to detect (Bailey et al. 2004). Snakes are well known for being extremely secretive and not readily observed even after intensive searching (Steen 2010), partly because their low energetic demands allow them to sustain long periods of inactivity (Willson et al. 2011). Still other species may have gone undetected as a result of our sampling methods. For example, many salamanders are active mainly during winter and early spring (Conant and Collins 1998), and we did not sample extensively at these times. We also focused primarily on riparian areas and may have failed to detect certain species such as the Slender Glass Lizard (Ophisaurus attenuatus), which typically inhabits dry grasslands (Conant and Collins 1998). Finally, undetected but potentially occurring species might have gone unobserved because they are experiencing local declines or extirpations in the area. Such declines, however, seem unlikely given that much of the area is relatively undisturbed habitat well suited to the requirements of a diverse array of amphibians and reptiles. Yet, recent research in the Broad River Basin (Eskew et al. 2012) and elsewhere (Voelz and Ward 1991; Nilsson and Svedmark 2002; Haxton and Findlay 2008) highlights the importance of flow regulation through damming determining species' distribution and abundances. The Broad River contains numerous dams which may affect the distributions of some species in the area.

Our study documented several species currently considered of Special Concern in South Carolina (SCDNR 2010; Table 3). Acris crepitans was very abundant across many of the study sites. At each site, all Acris collected or recorded during call surveys were identified as $A$. crepitans. Lithobates palustris was found to be somewhat rare (Table 1) $(n=19)$, but occurred in six out of the eight counties sampled. Several species which the South Carolina Department of Natural Resources recognizes as priority species were documented (Table 3), including Chamberlain's Dwarf Salamander (Eurycea chamberlaini), which was observed in Richland County and is considered a highest priority for conservation efforts (Table 1; SCDNR 2005). Additional species considered to be high priority by the SCDNR are the River Cooter (Pseudemys concinna) and the Spiny Softshell Turtle (Apalone spinifera), and of moderate priority are the Common Snapping Turtle (Chelydra serpentina) and Slider (Trachemys scripta). Pseudemys concinna was abundant in most riverine habitats and was documented in all eight counties which were surveyed. Apalone spinifera was documented in four counties, but it was seen infrequently $(n=6)$, likely because this species is secretive, often burying itself in soft mud and extending its neck so that only the nostrils 
Table 2. Documented reptiles of the Broad River Basin in South Carolina and the counties in which each was found. Species are classified as rare (1-5 observations), somewhat rare (6-20 observations), common (21-100 observations), or abundant (101 or more observations). Active searches (AS), and turtle trapping (TT) were conducted in Cherokee (Ck), Chester (Cs), Fairfield (F), Newberry (N), Richland (R), Spartanburg (S), Union (U), and York (Y) counties (In-incidental findings, Rk-roadkill).

\begin{tabular}{|c|c|c|c|c|}
\hline Scientific Name & Common Name & Abundance & Counties & Method of Detection \\
\hline Anolis carolinensis & Green Anole & Abundant & $\mathrm{Ck}, \mathrm{Cs}, \mathrm{F}, \mathrm{N}, \mathrm{R}, \mathrm{S}, \mathrm{U}, \mathrm{Y}$ & AS \\
\hline Aspidoscelis sexlineata & Six-lined Racerunner & Common & $\mathrm{F}$ & AS,In \\
\hline Eumeces fasciatus & Five-lined Skink & Somewhat rare & $\mathrm{Ck}, \mathrm{Cs}, \mathrm{N}, \mathrm{R}, \mathrm{U}, \mathrm{Y}$ & AS \\
\hline Eumeces inexpectatus & Southeastern Five-lined Skink & Rare & $\mathrm{F}, \mathrm{R}$ & AS \\
\hline Eumeces laticeps & Broadhead Skink & Somewhat rare & $\mathrm{N}, \mathrm{U}$ & AS \\
\hline Sceloporus undulatus & Northern Fence Lizard & Common & $\mathrm{Ck}, \mathrm{Cs}, \mathrm{R}$ & AS \\
\hline Scincella lateralis & Ground Skink & Common & $\mathrm{Ck}, \mathrm{Cs}, \mathrm{F}, \mathrm{N}, \mathrm{R}, \mathrm{U}$ & AS,In \\
\hline Agkistrodon contortrix & Copperhead & Rare & $\mathrm{Ck}, \mathrm{N}, \mathrm{U}$ & In \\
\hline Agkistrodon piscivorus & Cottonmouth & Rare & $\mathrm{R}$ & AS \\
\hline Carphophis amoenus & Eastern Worm Snake & Somewhat rare & $\mathrm{Ck}, \mathrm{Cs}, \mathrm{N}, \mathrm{S}$ & AS \\
\hline Coluber constrictor & Northern Black Racer & Rare & $\mathrm{Ck}, \mathrm{Cs}, \mathrm{F}, \mathrm{Y}$ & AS,In \\
\hline Diadophis punctatus & Ringneck Snake & Rare & $\mathrm{Ck}, \mathrm{Cs}, \mathrm{S}$ & $\mathrm{AS}$ \\
\hline Lampropeltis calligaster & Mole Kingsnake & Rare & $\mathrm{Y}$ & In \\
\hline Lampropeltis getula & Eastern Kingsnake & Rare & $\mathrm{Ck}, \mathrm{Cs}$ & AS \\
\hline Nerodia erythrogaster & Redbelly Watersnake & Rare & $\mathrm{R}$ & AS \\
\hline Nerodia sipedon & Northern Watersnake & Somewhat rare & $\mathrm{Ck}, \mathrm{Cs}, \mathrm{S}, \mathrm{U}$ & AS,In \\
\hline Nerodia taxispilota & Brown Watersnake & Somewhat rare & $\mathrm{Ck}, \mathrm{Cs}, \mathrm{F}, \mathrm{N}, \mathrm{R}, \mathrm{U}$ & AS \\
\hline Opheodrys aestivus & Rough Green Snake & Rare & $\mathrm{Cs}, \mathrm{N}, \mathrm{S}$ & $\mathrm{AS}, \mathrm{In}, \mathrm{Rk}$ \\
\hline Pantherophis guttatus & Corn Snake & Rare & $\mathrm{N}, \mathrm{Y}$ & In, $\mathrm{Rk}$ \\
\hline Pantherophis obsoletus & Black Rat Snake & Somewhat rare & $\mathrm{Ck}, \mathrm{Cs}, \mathrm{F}, \mathrm{N}, \mathrm{R}, \mathrm{S}, \mathrm{U}$ & AS,In, Rk \\
\hline Regina septemvittata & Queen Snake & Rare & $\mathrm{Ck}$ & AS \\
\hline Storeria dekayi & Brown Snake & Rare & $\mathrm{Ck}, \mathrm{R}$ & AS \\
\hline Storeria occipitomaculata & Red-bellied Snake & Rare & $\mathrm{Cs}$ & AS \\
\hline Apalone spinifera & Spiny Softshell Turtle & Somewhat rare & $\mathrm{Ck}, \mathrm{Cs}, \mathrm{F}, \mathrm{U}$ & AS,TT \\
\hline Chelydra serpentina & Common Snapping Turtle & Somewhat rare & $\mathrm{Ck}, \mathrm{Cs}, \mathrm{N}, \mathrm{R}, \mathrm{S}, \mathrm{U}$ & $\mathrm{AS}, \mathrm{TT}$ \\
\hline Chrysemys picta & Eastern Painted Turtle & Somewhat rare & $\mathrm{Ck}, \mathrm{F}, \mathrm{U}, \mathrm{Y}$ & AS \\
\hline Kinosternon subrubrum & Mud Turtle & Somewhat rare & $\mathrm{Cs}, \mathrm{R}, \mathrm{S}, \mathrm{Y}$ & AS \\
\hline Pseudemys concinna & Eastern River Cooter & Abundant & $\mathrm{Ck}, \mathrm{Cs}, \mathrm{F}, \mathrm{N}, \mathrm{R}, \mathrm{U}, \mathrm{Y}$ & AS,TT \\
\hline Sternotherus odoratus & Common Musk Turtle & Rare & $\mathrm{Ck}, \mathrm{N}, \mathrm{R}, \mathrm{U}$ & $\mathrm{AS}, \mathrm{TT}$ \\
\hline Terrapene carolina & Eastern Box Turtle & Common & $\mathrm{Ck}, \mathrm{Cs}, \mathrm{F}, \mathrm{R}, \mathrm{S}, \mathrm{U}, \mathrm{Y}$ & As,In \\
\hline Trachemys scripta & Yellow-bellied Slider & Common & $\mathrm{Ck}, \mathrm{F}, \mathrm{N}, \mathrm{R}, \mathrm{U}, \mathrm{Y}$ & AS,TT,In \\
\hline
\end{tabular}

break the surface of the water (Webb 1962; Martof et al. 1980; Ernst et al. 1994). Chelydra serpentina was found in Cherokee, Chester, Newberry, Richland, Spartanburg, and Union counties, but this species was also observed infrequently $(\mathrm{n}=6)$, likely a result of its crepuscular activity patterns (Smith and Iverson 2004). Chelydra serpentina also rarely basks out of water, which may make the species difficult to detect using some of our survey methods (Ernst et al. 1994). Trachemys scripta was abundant and was documented in all counties and $48 \%$ of active search sites.

Data from active searches and anuran calling surveys suggested that a combination of sampling methods is useful for detecting anurans. Most anurans were detected by both methods, but two species (Gastrophryne carolinensis and Scaphiopus holbrookii) were

Table 3. Rare amphibians and reptiles potentially occurring (-) or documented (X) within the Broad River Basin. Species of Special Concern (SC) are those native to South Carolina determined to be of concern. Priority Species (PS) are species listed in the South Carolina Wildlife Action Plan.

\begin{tabular}{llcc}
\hline \multicolumn{1}{c}{ Common Name } & \multicolumn{1}{c}{ Scientific Name } & Status in South Carolina & Observed \\
\hline Chamberlain's dwarf salamander & Eurycea chamberlaini & $\mathrm{X}$ \\
Four-toed Salamander & Hemidactylium scutatum & PS & - \\
Southern Dusky Salamander & Desmognathus auriculatus & PS & - \\
Northern Cricket Frog & Acris crepitans & SC & X \\
Pickerel Frog & Lithobates palustris & PC & $\mathrm{X}$ \\
River Cooter & Pseudemys concinna & PS & $\mathrm{X}$ \\
Yellowbelly Slider & Trachemys scripta & PS & $\mathrm{X}$ \\
Spiny Softshell Turtle & Apalone spinifera & PS & X \\
Common Snapping Turtle & Chelydra serpentina & SC & - \\
Timber/Canebrake Rattlesnake & Crotalus horridus & SC \\
Eastern Coral Snake & Micrurus fulvius & - \\
\hline
\end{tabular}


observed at some sites through active searches only. Furthermore, active searches increased the number of occurrence sites for some species. For example, Lithobates sphenocephalus was detected at 18 sites during active searches, but during calling surveys, we observed it only at 9 of those same sites. This species is known to venture relatively far from water during summer months (Dorcas and Gibbons 2008), which may have facilitated active search detection. Lithobates sphenocephalus breeds during early spring and fall in South Carolina, which is consistent with our results, since most calling by this species was heard in March and April, while most individuals were found during active searches between May and September. Lithobates sphenocephalus is also known to call after midnight in July (Bridges and Dorcas 2000). As most of our call surveys were completed by midnight, it is possible that in summer months this species went undetected.

As environmental issues (e.g., human population growth, habitat fragmentation, energy use, etc.) become more imminent, it is critical to understand distribution, abundance, and diversity patterns of species to ensure responsible resource management. Data obtained from this study represent a valuable inventory of herpetofaunal species in the Broad River Basin of South Carolina. This information is particularly important because little is known about the herpetofauna of South Carolina, especially in the Piedmont (Dorcas et al. 2006). Although the Broad River Basin contains relatively low levels of development, the urban centers of Spartanburg and Columbia are within the basin. Furthermore, several dams occur along the Broad and Pacolet Rivers, which have been shown to influence patterns of anuran distribution and abundance (Eskew et al. 2012). As water and energy demands continue to increase, the baseline data this study provides have important implications for conservation as well as future land management.

Acknowledgements: We thank L. Witczak, C. Williams, A. Domske, D. Millican, C. Oldham, R. Bauer, M. Abalo, B. Abbuhl, and C. Ruder for assistance in the field and J. Micancin for his help in identifying all Acris samples. G. Vaughan, S. Bennett, B. Perry, and V. Vejdani all assisted with logistics related to the project. Funding for this project was provided by the Broad River Mitigation trust fund administered through the South Carolina Department of Natural Resources. Additional funding was provided by the Duke Endowment through the Davidson Research Initiative and the Davidson College Department of Biology.

\section{LITERATURE CITED}

BAILEY, L. L., T. R. SIMONS, AND K. H. POLLOCK. 2004. Estimating detection probability parameters for Plethodon salamanders using the robust capture-recapture design. Journal Wildl. Mgt. 68:1-13.

BRIDGES, A. S., AND M. E. DORCAS. 2000. Temporal variation in anuran calling behavior: Implications for surveys and monitoring programs. Copeia 2000:587-592.

BURbrinK, F. T., C. A. PHILliPS, And E. J. HESKE. 1998. A riparian zone in southern Illinois as a potential dispersal corridor for reptiles and amphibians. Biol. Conserv. 86:107-115.

CONANT, R., AND J. T. COLLINS. 1998. Reptiles and Amphibians: Eastern/Central North America, 3rd ed. Houghton Mifflin Co., Boston, MA. 616 pp.

CONGDON, J. D., AND J. W. GIBBONS. 1989. Biomass productivity of turtles in freshwater wetlands: a geographic comparison. Pp. 583-592 in R. R. Sharitz and J. W. Gibbons (eds.), Freshwater Wetlands and Wildlife. Office Sci. Tech. Information, U.S. Dept. Energy, Oak Ridge, TN.

CRUMP, M. L., AND N. J. SCOTT, JR. 1994. Visual encounter surveys. Pp. 84-92 in W. R. Heyer, M. A. Donnelly, R. W. McDiarmid, L. C. Hayek, and M. S. Foster (eds.), Measuring and monitoring biological diversity: standard methods for amphibians. Smithson. Inst., Washington, D.C., USA. 556 pp.

DORCAS, M. E., AND J. W. GIBBONS. 2008. Frogs and Toads of the Southeast. Univer. of Georgia Press, Athens, GA. 238 pp.

DORCAS, M. E., S. J. PRICE, AND G. E. VAUGHAN. 2006. Amphibians and reptiles of the Great Falls Bypassed Reaches in South Carolina. J. No. Car. Acad. Sci. 122:1-9.

DORCAS, M. E., S. J. PRICE, S. C. WALLS, AND W. J. BARICHIVICH. 2009. Auditory monitoring of anuran populations. Pp. 281-298 in K. Dodd (ed.), Conservation and Ecology of Amphibians. Oxford Univer. Press, Oxford, U.K.

ERNST, C. H., J. E. LOVICH, AND R. W. BARBOUR. 1994. Turtles of the United States and Canada. Smithson. Inst. Press, Washington, D.C.. 578 pp.

ESKEW, E. A., S. J. PRICE, AND M. E. DORCAS. 2012. Effects of river-flow regulation on anuran occupancy and abundance in riparian zones. Conserv. Biol. 26:504-512.

ESRI INC. 2009. ArcInfo User's Manual, Version 9.3.1. Environmental Systems Research Institute Inc., Redlands, CA.

FAILEY, E. L., J. C. MCCOY, S. J. PRICE, AND M. E. DORCAS 2007. Ecology of turtles inhabiting golf course and farm ponds in the western Piedmont of North Carolina. J. No. Car. Acad. Sci. 123:221-232.

GIBBONS, J. W. 1988. The management of amphibians, reptiles, and small mammals in North America: the need for an environmental attitude adjustment. Pp. 4-10 in R. C. Szaro, K. E. Severson, and D. R. Patton (eds.), Mgt. of Amphibians, Reptiles, Small Mammals in North America. USDA Forest Service, Flagstaff, AZ.

GIBBONS, W. 1993. Keeping All the Pieces: Perspectives on Natural History and the Environment. Smithson. Inst. Press, Washington DC. $182 \mathrm{pp}$.

GIBBONS, J. W., AND M. E. DORCAS. 2004. North American Watersnakes: A Natural History. Univ. Oklahoma Press, Norman, OK. 438 pp.

GIBBONS, J. W., D. E. SCOTT, T. J. RYAN, K. A. BUHLMANN, T. D. TUBERVILLE, B. S. METTS, J. L. GREENE, T. MILLS, Y. LEIDEN, S. POPPY, AND C. T. WINNE. 2000. The global decline of reptiles, Déjà vu amphibians. BioScience 50:653-666.

GODLEY, J. S. 1980. Foraging ecology of the striped swamp snake, Regina alleni, in southern Florida. Ecol. Monogr. 50:411-436.

GOOCH, M. M., A. M. HEUPEL, S. J. PRICE, AND M. E. DORCAS. 2006. The effects of survey protocol on detection probabilities and site occupancy estimates of summer breeding anurans. Applied Herpetol. 3:129-142.

GRIFFITH, J. A., S. V. STEHMAN, AND T. R. LOVELAND. 2003. Landscape trends in Mid-Atlantic and Southeastern United States ecoregions. Environ. Mgt. 32:572-588. 
HAXTON, T. J., AND C. S. FINDLAY. 2008. Meta-analysis of the impacts of water management on aquatic communities. Canadian J. Fish. Aquatic Sci. 65:437-447.

KNUTSON, M. G., J. R. SAUER, D. A. OLSEN, M. J. MOSSMAN, L. M. HEMESATH, AND M. J. LANNOO. 1999. Effects of landscape composition and wetland fragmentation on frog and toad abundance and species richness in Iowa and Wisconsin, U.S.A. Cons. Biol. 13:1437-1446.

LANNOO, M. 2005. Amphibian Declines: The Conservation Status of United States Species. University of California Press. Berkeley Los Angeles, CA. 1094 pp.

MARTOF, B. S., W. M. PALMER, J. R. BAILEY, AND J. R. HARRISON, III. 1980. Amphibians and Reptiles of the Carolinas and Virginia. Univ. No. Car. Press. Chapel Hill, NC. 264 pp.

NILSSON, C., AND M. SVEDMARK. 2002. Basic principles and ecological consequences of changing water regimes: riparian plant communities. Environ. Mgt. 30:468-480.

NLCD (National Land Cover Data). 2011. Seamless Data Warehouse. 10 November 2011. <http://seamless.usgs.gov/index.php>.

North American Amphibian Monitoring Program: Protocal Description. 2010. USGS Patuxent Wildlife Research Center. 6 December USGS. 9 January 2012. <http://www.pwrc.usgs. gov/naamp $>$.

NWI (National Wetlands Inventory). 2011. Download Digital Data. 10 November $2011<$ http://www.fws.gov/wetlands/>.

PALMER, W. M., AND A. L. BRASWELL. 1995. Reptiles of North Carolina. Univ. No. Car. Press, Chapel Hill, NC. 412 pp.

PETRANKA, J., AND S. MURRAY. 2001. Effectiveness of removal sampling for determining salamander density and biomass: a case study in an Appalachian streamside community. J. Herpetol. 35:36-44.

POUGH, F. H. 1980. The advantages of ectothermy for tetrapods. The Amer. Nat. 115:92-112.

PRICE, S. J., AND M. E. DORCAS. 2011. The Carolina Herp Atlas: an online citizen-science approach to document amphibian and reptile occurrences. Herpetological Conserv. Biol. 6:287-296.

PRICE, S. J., M. E. DORCAS, A. L. GALLANT, R. W. KLAVER, AND J. D. WILLSON. 2006. Three decades of urbanization: estimating the impact of land cover change on stream salamander populations. Biol. Conserv. 133:436-441.

SCDHEC (South Carolina Department of Health and Environmental Control). 2011. "Broad River Basin." 9 January 2012. <http:// www.scdhec.gov/environment/water/shed/bd_bd.htm >.

SCDNR (South Carolina Department of Natural Resources). 2009. Broad Scenic River. 9 January 2012. <http://www.dnr.sc.gov/ water/envaff/river/scenic/broad.html $>$.

SCNDR (South Carolina Department of Natural Resources). 2009. South Carolina Comprehensive Wildlife Conservation Strategy 2005-2010. State Wildlife Action Plans. 28 September 2005. 9 January 2012. < http://www.wildlifeactionplans.org/south_ carolina.html>.

SC Rare, Threatened and Endangered Species Inventory. South Carolina Department of Natural Resources. 2010, South Carolina Department of Natural Resources. 9 January 2012. $<$ http://www.dnr.sc.gov/species/index.html $>$.

SEMLITSCH, R. D. eds. 2003. Amphibian Conservation. Smithson. Inst. Press, Washington, DC. $311 \mathrm{pp}$.

SMITH, G. R., AND J. B. IVERSON. 2004. Diel activity patterns of the turtle assemblage of a northern Indiana lake. Amer. Midl. Nat. 152:156-164

STEEN, D. A. 2010. Snakes in the grass: secretive natural histories defy both conventional and progressive statistics. Herpetological Conserv. Biol. 5:183-188.

TAYLOR, B. E., R. A. ESTES, J. H. K. PECHMANN, AND R. D. SEMLITSCH. 1988. Trophic relations in a temporary pond: larval salamanders and their microinvertebrate prey. Can. J. Zool. 66:2191-2198.

TUBERVILLE, T. D., J. D. WILLSON, M. E. DORCAS, AND J. W. GIBBONS. 2005. Herpetofaunal species richness of the southeastern national parks. Southeast. Nat. 4:537-569.

VITT, L. J., J. P. CALDWELL, H. M. WILBUR, AND D. C. SMITH. 1990. Amphibians as harbingers of decay. BioScience 40:418.

VOELZ, N. J., AND J. V. WARD. 1991. Biotic responses along the recovery gradient of a regulated stream. Can. J. Fish. and Aquatic Sci. 48:2477-2490.

WAKE, D. B., AND V. T. VREDENBURG. 2008. Are we in the midst of the sixth mass extinction? A view from the world of amphibians. Proc. Nat. Acad. Sci. 105:11466-11473.

WEBB, R. G. 1962. North American recent soft-shelled turtles (family Trionychidae). Univ. of Kansas Publ., Museum Nat. Hist. 13:429-611.

WILLSON, J. D., C. T. WINNE, AND B. D. TODD. 2011. Ecological and methodological factors affecting detectability and population estimation in elusive species. J. Wildl. Mgt. 75:36-45.

Appendix I. Potentially occurring species not documented during this study.

\begin{tabular}{ll}
\hline \multicolumn{1}{c}{ Scientific name } & \multicolumn{1}{c}{ Common name } \\
\hline Acris gryllus & Southern Cricket Frog \\
Anaxyrus quercicus & Oak Toad \\
Hyla femoralis & Pine Woods Treefrog \\
Hyla gratiosa & Barking Treefrog \\
Hyla squirella & Squirrel Treefrog \\
Lithobates capito & Gopher Frog \\
Lithobates virgatipes & Carpenter Frog \\
Pseudacris brimleyi & Brimley's Chorus Frog \\
Pseudacris nigrita & Southern Chorus Frog \\
Pseudacris ornata & Ornate Chorus Frog \\
Ambystoma talpoideum & Mole Salamander \\
Ambystoma tigrinum & Eastern Tiger Salamander \\
Desmognathus auriculatus & Southern Dusky Salamander \\
Eurycea quadridigitata & Dwarf Salamander \\
Hemidactylium scutatum & Four-toed Salamander \\
Necturus punctatus & Dwarf Waterdog \\
Plethodon chlorobryonis & Atlantic Coast Slimy Salamander \\
Pseudotriton montanus & Mud Salamander \\
Pseudotriton ruber & Red Salamander \\
Siren intermedia & Lesser Siren \\
Siren lacertina & Greater Siren \\
Ophisaurus attenuatus & Slender Glass Lizard \\
Ophisaurus ventralis & Eastern Glass Lizard \\
Cemophora coccinea & Scarlet Snake \\
Crotalus horridus & Timber Rattlesnake \\
Heterodon platirhinos & Eastern Hog-nosed Snake \\
Heterodon simus & Southern Hog-nosed Snake \\
Lampropeltis triangulum elapsoides & Scarlet Kingsnake \\
Masticophis flagellum & Eastern Coachwhip \\
Micrurus fulvius & Eastern Coral Snake \\
Nerodia fasciata & Banded Watersnake \\
Pituophis melanoleucus & Northern Pine Snake \\
Sistrurus miliarius & Pygmy Rattlesnake \\
Tantilla coronata & Southeastern Crown Snake \\
Thamnophis sauritus & Eastern Ribbon Snake \\
Thamnophis sirtalis & Common Garter Snake \\
Virginia striatula & Rough Earth Snake \\
Virginia valeriae & Smooth Earth Snake \\
\hline
\end{tabular}

